\title{
Halal Purchase Intention on Processed Food
}

\section{Saniatun Nurhasanah ${ }^{1}$, Happy Febrina Hariyani²}

\begin{abstract}
The objective of this study is to investigate the factors affecting customers on purchasing halal purchase intention on processed food. A purposive sampling method with 193 respondents and the data analysis is done by SEM-PLS method. The results show that halal awareness, health reason, and perceived value have a significant and positive direct effect on purchasing intention. Halal marketing also shows a significant and positive effect on purchasing intention. The food safety, halal certification, brand image, and perceived quality show the same effect which has no direct effect on purchasing intention. Furthermore, Food safety has an indirect effect on purchasing intention through health reason. Halal certification has an indirect effect on purchase intention through brand image variable. Meanwhile, brand image and perceived quality have an indirect effect through perceived value variable on purchasing intention.
\end{abstract}

Keywords: Halal Food, Purchase Intention, SEM

\begin{abstract}
Abstrak. Sebagai negara yang mayoritas penduduknya beragama Islam, peningkatan permintaan akan produk halal meningkatkan kesadaran masyarakat dalam mengkonsumsi produk halal dan menjadi potensi pasar yang sangat besar bagi produsen. Tujuan dari penelitian ini adalah menganalisa faktor-faktor yang mempengaruhi pelanggan pada halal purchase intention pada makanan olahan. Penelitian ini menggunakan metode purposive sampling dengan 193 responden dan analisis data dilakukan dengan metode SEM-PLS. Hasilnya menunjukkan bahwa halal awareness, health reason, dan perceived value memiliki pengaruh langsung yang signifikan dan positif terhadap purchase intention. Halal marketing juga menunjukkan pengaruh yang signifikan dan positif terhadap purchase intention. The food safety, halal certification, brand image, dan perceived quality menunjukkan efek yang sama yaitu tidak memiliki efek langsung pada purchase intention. Selanjutnya, food safety memiliki efek tidak langsung pada purchase intention melalui health reason. Halal certification memiliki pengaruh tidak langsung terhadap purchase intention melalui brand image. Sementara itu, brand image dan perceived quality memiliki efek tidak langsung melalui variabel perceived value pada purchase intention.
\end{abstract}

Kata kunci: makanan halal, purchase intention, SEM

\footnotetext{
${ }^{1}$ Islamic Business and Management Department, STEI Tazkia | saniatun@tazkia.ac.id ${ }^{2}$ Development Studies Department, University of Muhammadiyah Malang I happyfebrina02@gmail.com
} 


\section{Introduction}

\section{Halal Product in Global Halal Market}

Halal products refer to products that meet the syar' $i$ requirements that prevent prohibition, both in terms of substance and other substances (Burhanuddin, 2011). According to Al-Ghazali (2007), food can be haram because of its kind of haram, such as khamar, pig, etc., including the products of its derivatives (alcohol, gelatin, etc.), and it is haram because how to get it, including in the treasure to get it and the process of making it.

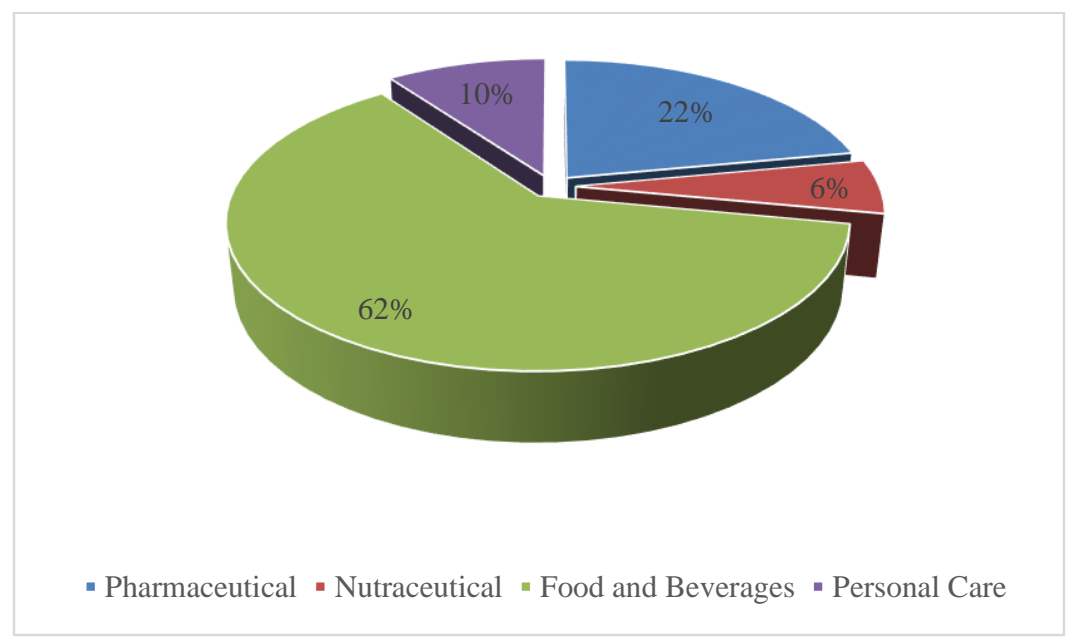

Figure 1. Global Market for Halal-Potential Products, 2015

Source: Euromonitor reports; FAOStat, 2015

The halal market has been qualified as the target market that can potentially be captured. Approximately $67 \%$ of these halal-potential products are categorized as fast moving consumer goods (FMCG). In Figure, 1.62\% of the global halal market potential is dominated by food and beverages.

Central Bureau of Statistics in 2010 stated that the number of moslem population in Indonesia reached 207 million or 87.18 percent of the population of Indonesia. The large market share of halal products will eventually become the large market of halal products. Based on a survey conducted by the research team of Majelis Ulama Indonesia (MUI) revealed 
that the level of awareness of Indonesian people to halal products increased significantly. On 2009, the level of public awareness of halal products is only about 70 percent, but it increases by the end of 2010 to around 92.2 percent, which means that this potential could make Indonesia be a world level halal producer (Syahruddin, 2014). The growing awareness of moslems around the world on their obligation to consume food that meets the requirements of the Islamic diet has created a greater demand for halal food and products (Ambali and Fuel, 2013).

Nowadays, halal is no longer purely as a religious issue, but in the realm of business and commerce (Borzooei and Asgari, 2013). Halal can be a distinguishing factor and by searching, highlighting and communicating halal certification, it may be able to expand into the world market (Rajagopal et al., 2011). The benefits of halal products affect the attitudes and behavior of consumers in terms of the intention to buy products and the willingness to pay for halal products (Aziz and Chok, 2013). Conversely, companies that ignore this halal issue will be left out by their customers and it will affect the company's overall profit.

This study is conducted to analyze the factors that affect halal purchase intention of processed food to consumers.

\section{Literature Review}

Halal means allowed, whereas haram means not allowed (Qaradhawi, 2013). Ahmad (2014) mentioned that the word halal is derived from the Arabic language, and it refers to Islamic belief, applied by moslems and it is defined as things or actions permitted by Islamic law without punishment imposed on the offender, as it is permitted by sharia law. In accordance with the rules of ushul fiqh, everything that is not prohibited by Allah means halal (Apriantono, 2005). According to Ambali and Bakar (2013), halal means permissible or lawful according to Islamic law and this also refers to food or products that are halal for moslem consumption. 
Halal food is food that is allowed to eat according to Islamic sharia. Halal drinks are drinks that are allowed to drink according to Islamic sharia. The halal and haram of food comes from God. Halal indicates that it contains nothing that is considered polluted in accordance with the sharia, halal meat indicates that animals have been slaughtered in accordance with the sharia.

In the Al-Qur'an, there are many commands on the consumption of halal food and the rules about the type of food that is forbidden, among others in Q.S. Al-Baqarah [2]: 172-173, Q.S Al-Maidah [5]: 3, Q.S. Al-An'am [6]: 145, QS An-Nahl [16]: 114, and QS Al-Maidah [5]: 90. Of those verses which include forbidden food; carcasses, blood, pigs, animals that when slaughtered are called names other than God, and khamer. Thus food and drinks as long as the ingredients and their management processes are not mixed with something that is haram is halal.

The halal concept emphasizes cleanliness, safety, hygiene, virtue, purity, manufacture, production, process, honesty, truth, and food service and other financial and social activities on an excellent platform from Islam (Hussein et al., 2016). Thus, halal food produced must have halal certification to ensure halal. In addition, food safety and health reason also become a reason in choosing halal food.

Halal certification is a certificate that states the origin of a product issued by a recognized and credible institution (Apriantono et al., 2007). Halal certificates are required for products (raw materials, ingredients, additives, packaging materials, etc.) and services (such as logistics, cleaning services, insurance) purchased and for animal-based products which it is important to know whether the animals slaughtered by machine or shot (Tieman and Ghazali, 2013). Especially for Indonesia, the recognized halal certification institution is the Institute for Assessment of Food, Drugs and Cosmetics of Majelis Ulama Indonesia (LPPOM MUI). While for products from abroad, recognized and credible institutions are institutions that have established cooperation relationships with Indonesia (MUI). Products containing animal elements (beef, chicken, goat, etc.) must have a halal certification. Likewise 
products that derive from animal derivatives, such as fat, gelatin, flavors must also have halal certification. This halal certification has its expiration date. Therefore, the company must immediately have a new halal certification to the supplier or manufacturer, when the validity period is expired.

Issa et al. (2009) states that halal certification is one way to inform and to convince consumers that the product is produced not only halal and shariacompliant, but also hygienic. Labels that are placed must be clear and meaningful to avoid confusion among consumers. Consumers are more concerned with halal logos and some moslem consumers prefer halal logos than ISO or similar certifications.

Moslem consumers demand healthy and qualified products that meet sharia requirements (Hussain et al., 2016). Not only are religious motives that determine public awareness about halal food or products for consumption, but also health issues related to religious identity and acculturation rates in whatever they consume daily, and also closely related to the argument for halal consumption because the main purpose of Allah (SWT) from halal is to ensure a healthy life for people (Ambali and Bakar, 2013).

Food safety is an important attribute for the purchase of food products (Hussain et al., 2016). In the Islamic perspective, under the shariah law, food safety meets the requirements of halal and thayyib (good).

Senthilnathan and Tharmi (2012) explained that purchase intention is a subjective tendency of consumers to certain products or services influenced by internal and external factors (such as choosing products, brands, retailers, time, and quantity); and consumers make purchasing decisions based on their individual qualities, personality, characteristics and decision-making processes, which can be an important element for predicting consumer behavior. Wang and Tsai (2014) defined purchase intention as a tendency of personal behavior and individual conscious plans to buy certain products in buying the brand based on the perceived benefits and value of consumers. While $\mathrm{Wu}$ (2011) stated that purchase intention represents the possibility that consumers will be planning or willing to buy certain products or services in 
the future, an increase in purchase intentions means an increased likelihood of purchase so that it can be used as an important indicator to predict consumer behavior.

Lee et al. (2011) stated that brand image consists of knowledge and beliefs about various brands of products and attributes of non-consumer products. Brand image is a personal symbolism that the consumer associates with the brand, which consists of all descriptive and evaluative brand information. Kotler (2009) defined brand image as the sum of the images, impressions and beliefs that a person has toward an object. Brand image is associated with an attitude of belief and preference for a brand.

Awareness is a concept that implies the ability to understand, feel, and become aware of events and objects, and play an important role in determining the intention to choose (Aziz and Chok, 2013). Awareness of halal principles determined by a positive attitude will determine the behavior in consuming or buying halal products. This is supported by Lada et al. (2009) that a positive attitude encourages the intention of choosing a halal product. Therefore, halal awareness can be conceptualized as a process of obtaining information in order to raise the level of awareness of what is permissible for moslems to eat, drink and use (Ambali and Bakar, 2013).

The halal food sector shares common standards with other conventional food sectors in terms of marketing, nevertheless has an explicit set of certain implications, in which moslem consumers are comparable to some of the other consumer groups in terms of demand for nutritious and superior food products. The difference comes from the need of compliant products (halal) (Cloud et al., 2015). According to Salehudin and Mukhlish (2012), halal marketing is the development of the concept of conventional marketing by adding aspects of compliance with Islamic sharia in the process of forming value for consumers. Therefore, it is important to look at each of the four tools of the marketing mix that can be used to satisfy customers and company goals as a way to evaluate their customers, how they respond according to the company's marketing strategy. Thus Salahudin and 
Mukhlish (2012) added that the scope of Halal Marketing is not only on the aspect of product (ie not containing the elements or raw materials that are forbidden) but also pricing, for example: pricing that does not contain gambling, gharar and riba) For example: not using fraud or perjury, not using sex appeal in the ads), and also place (for example: not selling at a prohibited place such as a mosque or at a prohibited time such as prayer time).

Perceived quality is the opinion of the consumer against the overall advantage, not the actual product quality, based on the information known to the consumer--intrinsic and extrinsic (Wang and Tsai, 2014). Perceived quality even has a substantial impact on buying interest, poor perceived quality will result in lower buying interest (Santoso, 2016).

Perceived value reflects the difference between expected quality and product benefits at the expense of cost (Wang and Tsai, 2014). Perceived value is positive when the value of quality is higher than the cost incurred. So perceived value can be an important indicator in predicting purchase intention.

\section{Method}

This research is to analyze factors influencing consumer purchase intention on processed food products that are marketed in supermarkets. The analysis used halal certification, halal awareness, and brand image as independent variables. Analytical tool used is Structural Equation Modeling. This study analyzes processed food products marketed in two Hypermarket namely: Giant and Hypermart, two supermarkets namely Superindo and Yogya, and two minimarkets namely Alfamart and Indomart in Jakarta, Bogor, Depok, Tangerang, and Bekasi.

Then, a descriptive analysis is used to describe and explain the consumer characteristics of the processed food product. After obtained the result of analysis from SEM and descriptive analalis then arranged managerial implication and recommendation addressed to processed food producer. The research framework is presented in figure 2. 


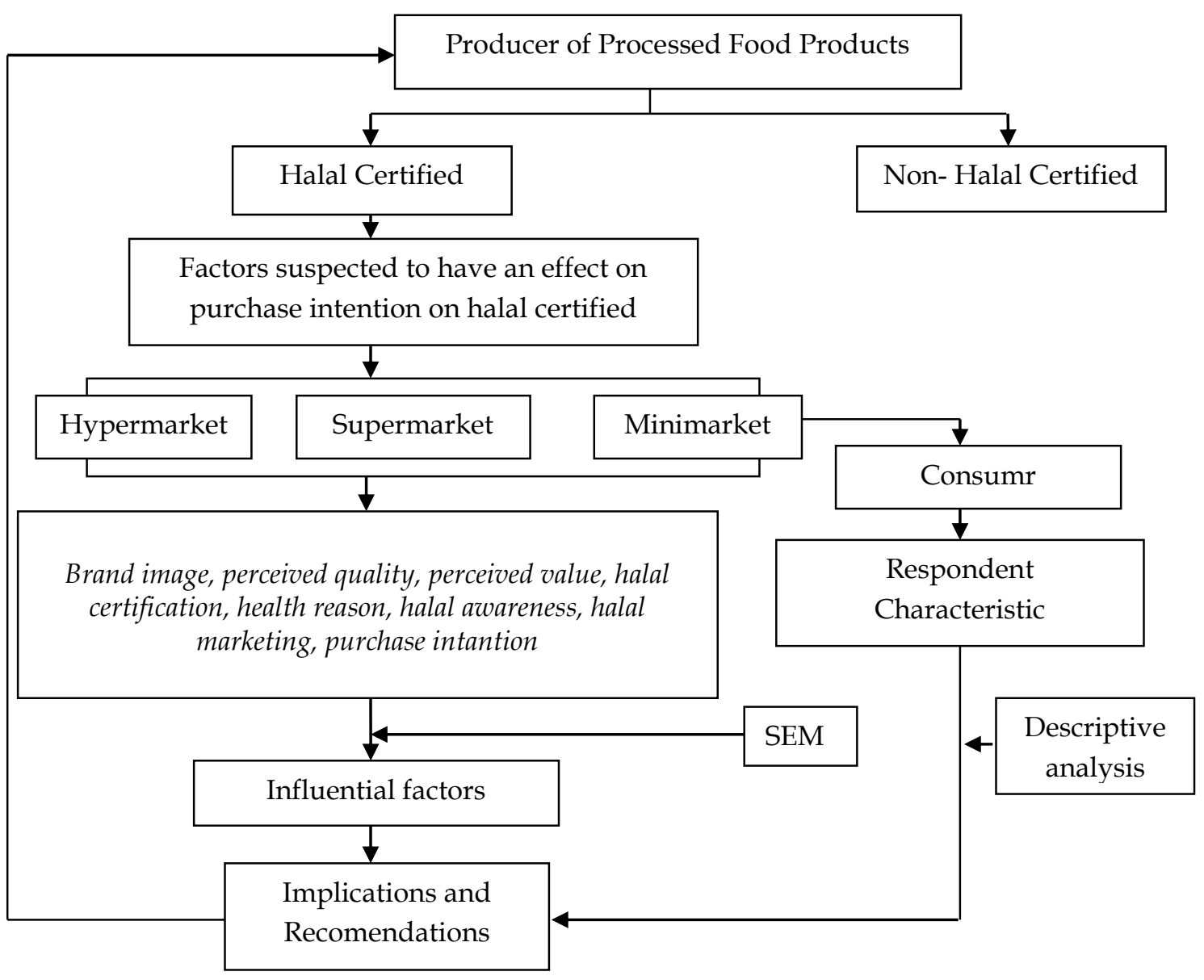

Figure 2. Research Framework

\section{Hypothesis}

H1 : Brand image has a positive effect on perceived quality.

H2 : Brand image has a positive effect on perceived value.

H3 : Food safety has a positive effect on health reasons.

H4 : Halal awareness has a positive effect on purchase intention.

H5 : Halal certification has a positive effect on brand image.

H6 : Halal marketing has a positive effect on brand image.

H7 : Halal marketing has a positive effect on purchase intention.

H8 : Health reasons has a positive effect on purchase intention.

H9 : Perceived quality has a positive effect on perceived value.

H10 : Perceived value has a positive effect on purchase intention. 
Based on the hypothesis above, it can create a description of research model of structural equation modeling. The research model is presented in figure 3.

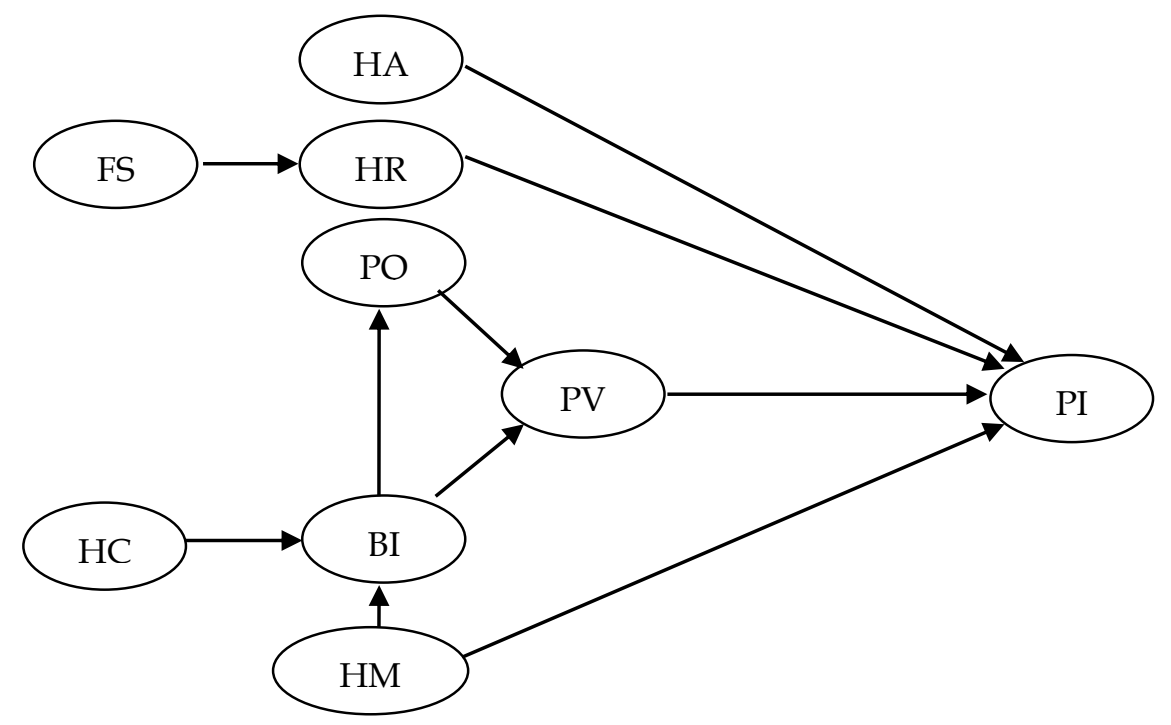

Figure 3. Research Model

Description:

HA (halal awareness), FS (food safety), HR (health reason), PQ (perceived quality), PV (perceived value), BI (brand image), HC (halal certification), HM (halal marketing), PI (purchase intention).

The data used are primary and secondary data. Primary data obtained from the survey to the object of research. The object of the research is consumers who buy processed food products on supermarkets and minimarkets in the area of Jakarta, Bogor, Depok, Tangerang, and Bekasi. The study is conducted for one month using questionnaires to the respondents directly and distributed questionnaires directly to the respondents and online through google form application spread through social media. While the secondary data obtained from various sources of literature, whether in the form of books, journals, previous research, internet and relevant data related to this research. In the questionnaire, the scale used is Likert scale based on the level of respondent approval on each indicator (1-6). 


\section{The Analysis of Structural Eqiation Modeling (SEM)}

Ghazali (2008) explained that Structural Equation Modeling (SEM) is a model of structural equation which is a simultaneous equation that focuses on the predictions which is capable of describing latent variables (indirect measurable) and indirectly measured based on indicators (manifest variables). SEM for social science researchers provides the ability to provide path analysis with latent variables. SEM analysis has a higher flexibility for researchers to link existing theory.

According to Latan (2013), SEM is the second generation multivariate analysis technique that links between factor analysis and path analysis to allow researchers to simultaneously test and estimate the relationship between multiple exogenous and endogenous variables with many factors. Thus, SEM can be used to address various research problems in a systematic and comprehensive set of analyzes.

Thus, there are at least two research problems to be answered through this SEM (Kusnendi, 2008). First, the problem of descriptive research, the description empirically confirms the suitability of the construct model which is seen according to the indicators conceived as the manifest of the construct. And second, the problem of explanatory research, explaining the causal relationship between latent variables. This second problem is called a structural model. Analyzed in SEM is the relationship between the latent variable (unobserved variable) and not between the manifest variable or between the indicator variables (observed variable).

Table 1. Operational Variabel

\begin{tabular}{|c|c|c|c|}
\hline Variabel & Indicator & Code & Scale \\
\hline Halal Awareness & a. The certainty of halal products & HA1 & Ordinal \\
\hline \multirow[t]{3}{*}{ (Awan, 2015) } & b. The halal responsible & HA2 & \\
\hline & $\begin{array}{l}\text { c. Supermarkets that are responsible for halal } \\
\text { products }\end{array}$ & HA3 & \\
\hline & d. Purchase halal products if there is a halal label & HA4 & \\
\hline
\end{tabular}


TIFBR | Tazkia Islamic Finance and Business Review

Volume 11(2), 2017

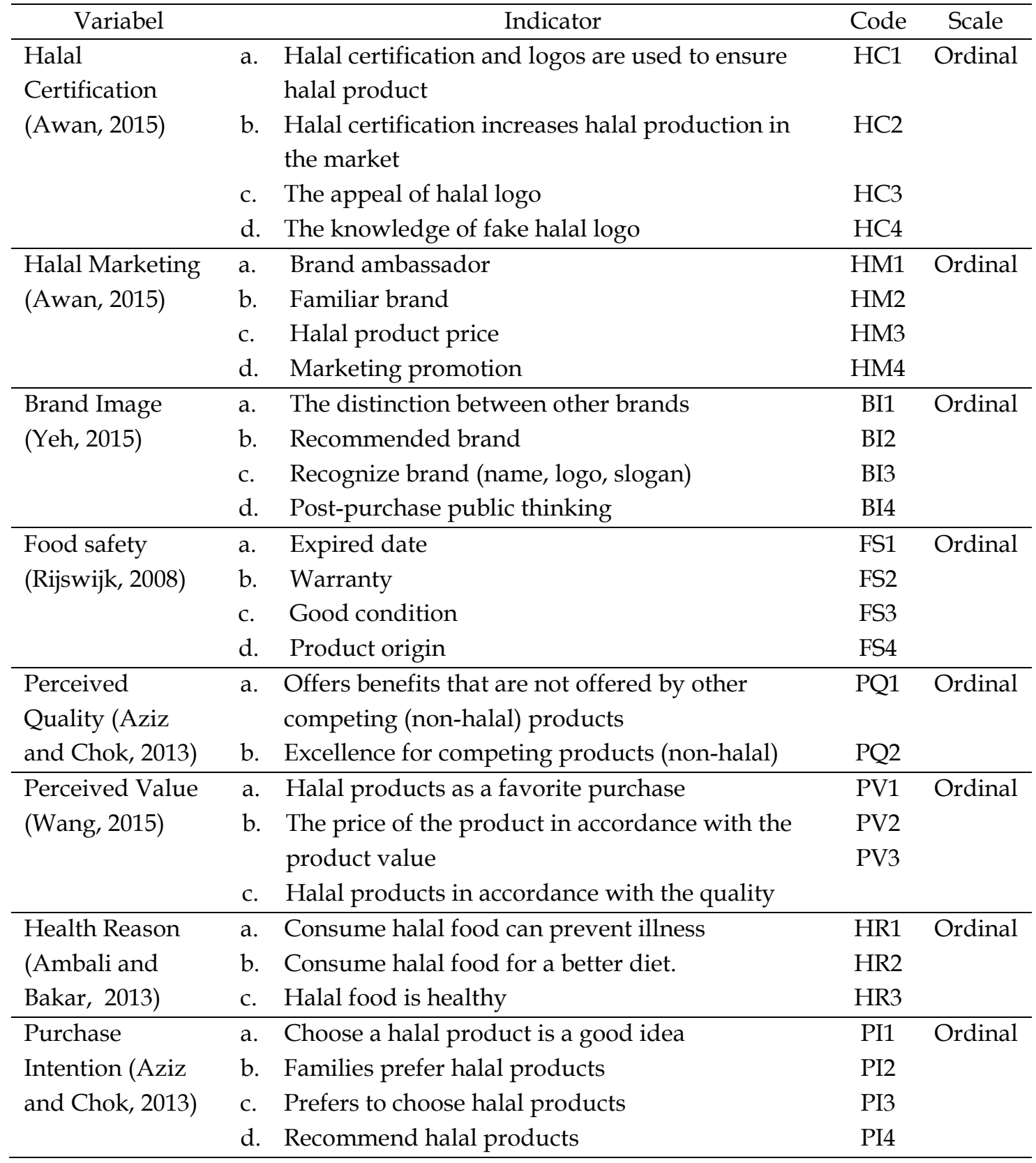

\section{Result and Discussion}

\section{Respondent Characteristic}

This study uses a questionnaire in the form of questionnaires to obtain data from each variable contained in the research model. The number of questionnaires successfully collected after verification, only 193 questionnaires can be continued in data processing. Table 2 presents the description of respondents based on the criteria of domicile areas, gender, age, last education, occupation, and income per month. 
Table 2. Respondent Characteristic

\begin{tabular}{|c|c|c|c|}
\hline Characteristic & Description & Quantity (People) & Percentage $(\%)$ \\
\hline \multirow[t]{5}{*}{ Domicile Area } & Jakarta & 16 & 8.3 \\
\hline & Bogor & 149 & 77.2 \\
\hline & Depok & 13 & 6.7 \\
\hline & Tanggerang & 8 & 4.2 \\
\hline & Bekasi & 7 & 3.6 \\
\hline \multirow[t]{2}{*}{ Gender } & Male & 62 & 32.1 \\
\hline & Female & 131 & 67.9 \\
\hline \multirow[t]{5}{*}{ Age } & $17-25$ y.o & 81 & 42.0 \\
\hline & $26-35$ y.o & 73 & 37.8 \\
\hline & $36-45$ у.о & 24 & 12.4 \\
\hline & $46-55$ y.o & 14 & 7.3 \\
\hline & $>55$ y.o & 1 & 0.5 \\
\hline \multirow[t]{7}{*}{ Education } & Elementary School & 11 & 5.7 \\
\hline & Junior High School & 7 & 3.6 \\
\hline & Senior High School & 41 & 21.2 \\
\hline & Diploma Degree & 9 & 4.7 \\
\hline & Bachelor Degree & 102 & 52.8 \\
\hline & Master Degree & 23 & 11.9 \\
\hline & Doctoral Degree & 0 & 0 \\
\hline \multirow[t]{5}{*}{ Occupation } & Government employees & 7 & 3.6 \\
\hline & Private employees & 66 & 34.2 \\
\hline & Housewife & 43 & 22.3 \\
\hline & Student & 58 & 30.1 \\
\hline & Others & 19 & 9.8 \\
\hline \multirow[t]{4}{*}{ Income per month } & $<$ IDR $1,000,000$ & 66 & 34.2 \\
\hline & IDR 1,000,000 - IDR 3,000,000 & 60 & 31.1 \\
\hline & IDR 3,000,000 - IDR 6,000,000 & 36 & 18.7 \\
\hline & $>$ IDR $6,000,000$ & 31 & 16.1 \\
\hline
\end{tabular}

Respondents are people from Jabodetabek area (Jakarta, Bogor, Depok, Tanggerang, and Bekasi). Respondents from Jakarta are 16 people $(8.3 \%)$, Bogor with 149 people (77.2\%), Depok with 13 people (6.7\%), Tangerang with 8 people $(4.1 \%)$ and Bekasi with 7 people $(3.6 \%)$. Based on gender, most respondents are female (67.9\%). They are divided into five age groups. Age 
group of $17-25$ years old $(42.0 \%)$ and age $26-35$ years $(37.8 \%)$ dominated the respondents.

In terms of education, most respondents are bachelor graduates as much as $52.8 \%$ followed by high school graduates as much as $21.2 \%$. They work as private employees (34.2\%), government employees (3.6\%), housewives $(22.3 \%)$, students $(30.1 \%)$ and others $(9.8 \%)$. Based on the income per month, the respondents are dominated by those with income less than 1,000,000 IDR (34.2\%) and income between 1,000,000 IDR and 3,000,000 IDR $(31.1 \%)$.

\section{The Analysis of Structural Equation Modeling}

The analysis in SEM model can be divided into two stages namely measurement model and structural analysis model. The purpose of doing the measurement model is to find out how strong the manifest variable describes each exogenous and endogenous latent variable. The purpose of analyzing the structural model is to know the correlation of exogenous latent variable with endogenous latent variable.

The PLS-SEM assessment usually follows a two-step process involving a separate assessment of the model's measurement of a structural model (Heir, 2011). Analysis of the model of measurement or outer model is done through confirmatory analysis with convergent validity test, and composite reliability test (Mulyono, 2016).

The reflective measurement model should be assessed with focus on their reliability and validity (Heir, 2011). According to Asyraf (2013), the value of this indicator is acceptable when the outer loading value is 0.50 or higher to maintain the measurement model. The value of outer loading for each research variable can be seen in table 3.

Based on the analysis, it is known that the value of outer loading for all indicators used in this study is above 0.5. This indicates that the indicators can reflect the variables and are declared valid. Based on the results of the outer 
TIFBR | Tazkia Islamic Finance and Business Review

Volume 11(2), 2017

loading values listed in table 3, indicate that all indicators are declared valid for use in research.

Table 3. Outer Loading Value

\begin{tabular}{lccccc}
\hline $\begin{array}{c}\text { Laten } \\
\text { Variable }\end{array}$ & Indicator & $\begin{array}{c}\text { Outer } \\
\text { Loading }\end{array}$ & $\begin{array}{c}\text { Laten } \\
\text { Variable }\end{array}$ & Indicator & $\begin{array}{c}\text { Outer } \\
\text { Loading }\end{array}$ \\
\hline Brand Image & BI1 & 0.568 & Health Reason & HR1 & 0.865 \\
& BI2 & 0.781 & & HR2 & 0.616 \\
& BI3 & 0.833 & & HR3 & 0.893 \\
& BI4 & 0.709 & & & \\
\hline Food Safety & FS1 & 0.816 & Perceived & PQ1 & 0.853 \\
& FS2 & 0.872 & Quality & PQ2 & 0.910 \\
& FS3 & 0.870 & & & \\
\hline Halal & FS4 & 0.761 & & & 0.724 \\
Awareness & HA1 & 0.890 & Perceived & PV1 & 0.758 \\
& HA2 & 0.799 & Value & PV2 & 0.791 \\
& HA3 & 0.688 & & PV3 & \\
\hline Halal & HA4 & 0.805 & & & 0.860 \\
Certification & HC1 & 0.779 & Purchase & PI1 & 0.866 \\
Halal & HC2 & 0.885 & Intention & PI2 & 0.932 \\
Marketing & HC3 & 0.869 & & PI3 & 0.730 \\
& HM1 & 0.636 & & PI4 & \\
& HM2 & 0.808 & & & \\
\hline
\end{tabular}

Source: Processed Data (2017)

In addition, the convergence validity test also see the value of Average Variance Exracted (AVE). AVE value is acceptable when value is greater than 0.50 AVE values of 0.50 and higher, indicating a sufficient level for convergent validity, meaning that latent variables account for more than half of the diversity of indicators.

Furthermore, the measurement consistency level (reliablitas) is tested with composite realibility. High reliability shows that indicators have a high consistency in measuring latent variables. In addition to composite realibility, reliability can also be seen from the value of composite realibility and cronbach's alpha is good if it has a value greater than 0.6. Therefore, all requirements for convergent test, construct reliability, cronbach's alpha or internal reliability are achieved. The value of AVE, composite realibility, and cronbach's alpha can be seen in table 4 . 
TIFBR | Tazkia Islamic Finance and Business Review

Volume 11(2), 2017

Table 4. The Value of Cronbach's Alpha, Composite Reliability, and AVE

\begin{tabular}{lccc}
\hline Cronbach's Alpha & Composite Reliability & $\begin{array}{c}\text { Average Variance } \\
\text { Extracted (AVE) }\end{array}$ \\
\hline Brand Image & 0.705 & 0.817 & 0.532 \\
Halal Awareness & 0.851 & 0.899 & 0.690 \\
Food Safety & 0.811 & 0.875 & 0.638 \\
Halal Certification & 0.800 & 0.883 & 0.715 \\
Halal Marketing & 0.562 & 0.746 & 0.428 \\
Health Reason & 0.711 & 0.840 & 0.642 \\
Perceived Quality & 0.630 & 0.802 & 0.574 \\
Perceived Value & 0.717 & 0.875 & 0.778 \\
Purchase Intention & 0.870 & 0.912 & 0.723 \\
\hline
\end{tabular}

Based on the value of AVE, convergence validity test indicators reflect that latent variables are expressed to have validity, unless the halal marketing variables have an AVE value of 0.428. Meanwhile, from Table 4 it can be seen that all latent variables in this study have composite realibility value above 0.6 and cronbach's alpha value above 0.6 so it can be stated that the variables used are reliable. But on the halal marketing variables, cronbach's alpha value for each is 0.562 , while the value of composite realibility shows the value above 0.6 so that this variable can still be declared quite reliable. This means that the indicators used in the study have a good consistency in measuring the latent variables.

\section{Structural Model Analysis}

Structural model analysis is performed to analyze and discuss the influence of exogenous latent variables on endogenous latent variables. The result of structural model analysis using t-count value is shown in table 5 and figure 4 .

The results illustrate that there are seven accepted hypotheses and three hypotheses rejected. The hypothesis is accepted if the t-statistic value is more than $\mathrm{t}$-table. The $\mathrm{t}$-table value specified is 1.96 based on $\mathrm{a}=5 \%$. 


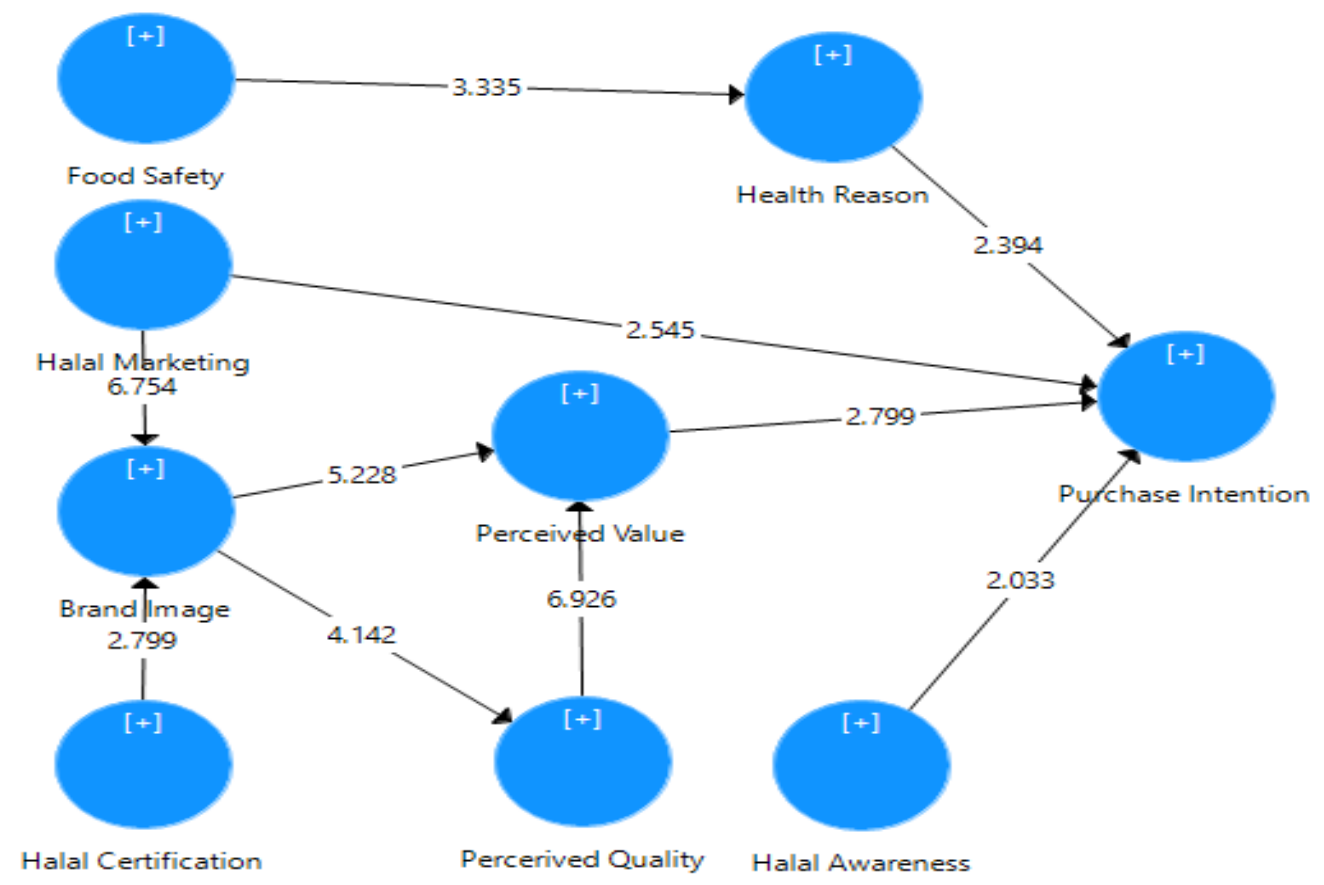

Figure 4. The Result of Structural Model Bootstraping

Table 5. The Result of Structural Model Analysis

\begin{tabular}{llccll}
\hline Hypothesis & \multicolumn{1}{c}{ Path } & T Statistics & Coefisien & Effect & $\begin{array}{c}\text { Hypothesis } \\
\text { Decision }\end{array}$ \\
\hline H1 & $\begin{array}{l}\text { Brand Image } \rightarrow \\
\text { Perceived Quality }\end{array}$ & 4.142 & 0.395 & $\begin{array}{l}\text { Significant and } \\
\text { Positive }\end{array}$ & Accepted \\
\hline H2 & $\begin{array}{l}\text { Brand Image } \rightarrow \\
\text { Perceived Value }\end{array}$ & 5.228 & 0.306 & $\begin{array}{l}\text { Significant and } \\
\text { Positive }\end{array}$ & Accepted \\
\hline H3 & $\begin{array}{l}\text { Food Safety } \rightarrow \\
\text { Health Reason }\end{array}$ & 3.335 & 0.306 & $\begin{array}{l}\text { Significant and } \\
\text { Positive }\end{array}$ & Accepted \\
\hline H4 & $\begin{array}{l}\text { Halal Awareness } \rightarrow \\
\text { Purchase Intention }\end{array}$ & 2.033 & 0.200 & $\begin{array}{l}\text { Significant and } \\
\text { Positive }\end{array}$ & Accepted \\
\hline H5 & $\begin{array}{l}\text { Halal Certification } \\
\rightarrow \text { Brand Image }\end{array}$ & 2.799 & 0.267 & $\begin{array}{l}\text { Significant and } \\
\text { Positive }\end{array}$ & Accepted \\
\hline H6 & $\begin{array}{l}\text { Halal Marketing } \rightarrow \\
\text { Brand Image }\end{array}$ & 6.754 & 0.468 & $\begin{array}{l}\text { Significant and } \\
\text { Positive }\end{array}$ & Accepted \\
\hline H7 & $\begin{array}{l}\text { Halal Marketing } \rightarrow \\
\text { Purchase Intention }\end{array}$ & 2.545 & -0.180 & $\begin{array}{l}\text { Significant and } \\
\text { Negative }\end{array}$ & Accepted \\
\hline H8 & $\begin{array}{l}\text { Health Reason } \rightarrow \\
\text { Purchase Intention }\end{array}$ & 2.394 & 0.210 & $\begin{array}{l}\text { Significant and } \\
\text { Positive }\end{array}$ & Accepted \\
\hline H9 & $\begin{array}{l}\text { Perceived Quality } \rightarrow \\
\text { Perceived Value }\end{array}$ & 2.799 & 0.227 & $\begin{array}{l}\text { Significant and } \\
\text { Positive }\end{array}$ & Accepted \\
\hline H10 & $\begin{array}{l}\text { Perceived Value } \rightarrow \\
\text { Purchase Intention }\end{array}$ & 6.926 & 0.451 & $\begin{array}{l}\text { Significant and } \\
\text { Positive }\end{array}$ & Accepted \\
\hline
\end{tabular}

Source: Processed Data (2017) 
The Effect of Brand Image on Perceived Quality

Table 5 explains that the brand image has a positive effect on perceived quality, with a $\mathrm{t}$ value of 4.142 . These results are consistent with Wang and Tsai's findings (2014). This shows that halal food products with brands and which have been widely recognized and considered good after purchase as a very strong factor reflects the image of the brand. So, the better the brand image of a halal food product, the better the consumer's perception of product quality.

\section{The Effect of Brand ImageonPerceived Value}

Based on research conducted by Wang and Tsai (2014), brand image gives positive influence to perceived value. In this study, similar results also found that the brand image gives a positive effect on perceived value, shown with a $t$ value of 5.228. It is increasingly convincing that the better the brand image of halal food products will increase the perception of the value of a good product in the eyes of consumers.

\section{The Effect of Halal Awareness onPurchase Intention}

Based on the results in table 5 , it can be seen that halal awareness has a significant positive effect on purchase intention. The $t$ value is 2.033 , because it has a value> 1.96, so the hypothesis decision is accepted. It means that the awareness of moslem society to buy halal processed food products is high. This is in line with previous research conducted by Hamdan et al. (2013) and Aziz and Chok (2013), although different from the results shown by Cloud et al. (2015) which states halal awareness has no significant effect.

\section{The Effect of Halal Marketing onPurchase Intention}

The results show that halal marketing has a significantly negative effect on halal maketing, with a value of $t$ that is 2.545 and the coefficient of 0.180. This finding is inconsistent with the findings of Cloud et al. (2015). This suggests that people buying halal food products do not see the brand ambassador and prices that become indicators of marketing variables to influence people in buying halal food. Halal food demanded to be purchased 
because it is halal, not because of the marketing process offered. So this result shows that in the process of marketing halal food products, should be more emphasis on promoting halal products than the reliability of promotions with brand ambassador and prices.

\section{The Effect of Health Reasonon Purchase Intention}

In a previous study conducted by Hussain et al. (2016), showed that health is a factor affecting purchase intention. The results showed that the health reason variable showed a positive value and significant effect on purchase intention. This suggests that people buy halal food because they believe that by consuming halal food can prevent from illness, have a better and healthier diet. So, this reason can encourage them to purchase halal processed food products.

\section{The Effect of Perceived Quality on Perceived Value}

Based on research by Wang and Tsai (2014), perceived quality has a positive effect on perceived value. In this study, a similar result also found that perceived quality has a positive effect on perceived value, indicated by a $t$ value of 2,799. These results show the consumer's perception of the quality of halal food products is directly proportional to the perception of the value of these halal food products. So the better perceived quality, the better perception of the value is.

\section{The Effect Perceived Valueon Purchase Intention}

Based on the result, perceived value gives a positive effect to purchase intention, with $t$ value of 6.926 . The results of this study is supported by the Wang and Tsai (2014) that shows similar results. In this case, a good value perception can encourage consumers to make purchases. The perceived value is that halal food is a favorite of purchase, the price of the food is in the value, and has the corresponding value. 
The evaluation of indirect effect is conducted to determine the effect of moderation variables among exogenous and endogenous variables. The results of indirect effect evaluation are presented in table 6 .

Table 6. Indirect Effect Value between Variables

\begin{tabular}{cc}
\hline Relationship between variables & Indirect Effect Value \\
\hline $\mathrm{BI} \rightarrow \mathrm{PI}$ & 0.110 \\
$\mathrm{FS} \rightarrow \mathrm{PI}$ & 0.064 \\
$\mathrm{HC} \rightarrow \mathrm{PI}$ & 0.029 \\
$\mathrm{HM} \rightarrow \mathrm{PI}$ & 0.052 \\
$\mathrm{PQ} \rightarrow \mathrm{PI}$ & 0.103
\end{tabular}

Source: Processed Data (2017)

Food safety, halal certification, brand image and perceived quality have no direct effect on purchase intention. Food safety variables have an indirect effect on purchase intention through health reason of 0.064 . This means that food safety factors increase health reasons for consumers in choosing halal food products, although many of the consumers do not directly pay attention to food safety in determining the purchase.

Halal certification and halal marketing also has an indirect effect on purchase intention through brand image variables in sequence 0.029 and 0.052. Although halal certification does not directly affect consumer purchase intention, halal certification can improve the brand image of food products. With the existence of halal certification, brand image of food products will be better especially among moslem consumers.

Brand image and perceived quality have no direct effect on purchase intention. Brand image variable has an indirect effect on purchase intention through perceived value and perceived quality of 0.110 . Similarly, perceived quality has indirect effect on purchase intention of 0.103 . This is in line with the study conducted by Wang and Tsai (2014) where although the brand image has no direct effect on purchase intention significantly, it still has an indirect effect on purchase intention. 
Based on the results of this study, shows that some research variabel directly affect buying interest. Therefore, some managerial implications can be made to increase consumer buying interest in halal food products.

In the process of halal food products marketing, manufacturers do not need to highlight brands, brand ambassador (celebrity endorsement), prices, and other sales promotions. Therefore, the most important thing is to show the halal of the product. For the government, the Indonesian Council of Ulama (MUI), it is necessary to continuously improve the socialization of halal-certified products. It is also necessary to socialize the official halal logo used by domestic products and imported products.

\section{Conclusion}

The result using SEM-PLS showed that the variable of halal awareness, health reason, and perceived value showed a significant and positive influence on purchase intention. This shows the higher consumer awareness of halal product, health and perceived value increasingly encourage consumer interest to buy halal food products. Of the three variables that have the most influence is the health reason variable with a $t$ value of 2.253. As for halal marketing gives a significant but negative effect which means that the marketing process is necessary but not necessarily accentuate the elements of brand ambassadors and prices. Halal marketing also gives a significant and positive influence on brand image. While the food safety variable, halal certification, brand image, and perceived quality have no direct effect on purchase intention. Food safety has an indirect effect on buying interest through health reason. Halal certification has an indirect effect on buying interest through brand image variables. Meanwhile, brand image, and perceived quality have indirect effect through perceived value variable to purchase intention, meaning that brand image and good quality perception will encourage increasing perception of value from product, increasing perception of this value that can increase consumer purchase intention. 


\section{References}

Ahmad, M.F. (2014). Antecedents of Halal Brand Personality. Journal of Islamic Marketing, Vol. 6(2): 209-223.

Al-Ghazali, I. (2007). Rahasia Halal-Haram: Hakikat Batin Perintah dan Larangan Allah. Bandung (ID): Mizan Media Utama.

Ambali, A.R. and Bakar, A.N. (2013). Halāl Food and Products in Malaysia: People's Awareness and Policy Implications. IIUM Press Intellectual Discourse, Vol. 21(1): 7-32.

Apriyantono, Anton. (2005). Makanan dan Minuman Halal. Bandung (ID): Kiblat Buku Utama.

Apriyantono, A. Hermanianto, J. and Wahid N. (2007). Pedoman Produksi Pangan Halal. Jakarta (ID): Khairul Bayan Press.

Asyraf, W. M. (2013). A Comparison of Partial Least Square Structural Equation Modeling (PLS-SEM) and Covariance Based Structural Equation Modeling (CB-SEM) for Confirmatory Factor Analysis. International Journal of Engineering Science and Innovative Technology (IJESIT), Vol. 2.

Awan, H.M. Siddiquei, A.N. and Haider, Z. (2015). Factors Affecting Halal Purchase Intention - Evidence From Pakistan's Halal Food Sector. Management Research Review, Vol. 38(6).

Aziz, Y.A. and Chok, N.V. (2013). The Role of Halal Awareness, Halal Certification, and Marketing Components in Determining Halal Purchase Intention Among Non-Muslims in Malaysia: A Structural Equation Modeling Approach. Journal of International Food $\mathcal{E}$ Agribusiness Marketing, Vol. 25(1): 23.

Borzooei, M. and Asgari, M. (2013). The Halal Brand Personality and Its Effect on Purchase Intention. Interdisciplinary Journal of Contemporary Research in Business, Vol. 5(3)

Burhanuddin. (2011). Pemikiran Hukum Perlindungan Konsumen dan Halal Certification. Malang (ID): UIN-MALIKI Press.

Feuss, W.J. (2003). The Post-Purchase Impact of Brand Image. [Disertasi]. Hoboken: Stevens Institute of Technology.

Ghazali, I. (2008). Structural Equation Modeling Metode Alternatif dengan Partial Least Square. Semarang: Badan Penerbit Universitas Diponogoro.

Ghozali, I. and Latan, H. (2015). Partial Least Square Konsep, Tekni, dan Aplikasi Menggunakan SmartPLS 3.0. Semarang: Badan Penerbit Universitas Diponogoro.

Hair, J.F. Ringle, C.M. and Sarstedt, M. (2011). PLS-SEM: Indeed a Silver Bullet. Journal of Marketing Theory and Practice, Vol. 19(2), 139-15. 
Hamdan, H. et al. (2013). Purchasing Decisions among Muslim Consumers of Processed Halal Food Products. Journal of Food Products Marketing, Vol. 19: 54-61.

Hussain, I. et al. (2016). Integrating Factors Influencing Consumers' Halal Products Purchase: Application of Theory of Reasoned Action. Journal of International Food \& Agribusiness Marketing.

Issa, Z.M. et al. (2009). Practices of Food Producers in Producing Halal Food. Interdisciplinary Journal of Conpemporary Research in Business, Vol. 1(7).

Kotler, P. and Keller, K.L. (2009). Manajemen Pemasaran Edisi 13 Jilid 1. Jakarta (ID): Penerbit Erlangga.

Kusnendi. (2008). Model-Model Persamaan Struktural. Bandung (ID): Alfabeta.

Lada, S. Tanakinjal, G.H. and Amin, H. (2009). Predicting Intention to Choose Halal Products Using Theory of Reasoned Action. International Journal of Islamic and Middle Eastern Finance and Management, Vol. 2(1).

Latan, H. (2013). Struktural Equation Modeling: Konsep dan Aplikasi menggunakan Program LISREL 8.80. Bandung (ID): Penerbit Alfabeta.

Lee, H.M. Lee, C.C. and Wu, C.C. (2011). Brand Image Strategy Affects Brand Equity After M\&A. European Journal of Marketing, Vol. 45(7/8).

LPPOM MUI. (2008). Persyaratan Halal Certification. Retrieved from: http://www.halalmui.org/newMUI/index.php/main/go_to_section/ 39/1328/page/1.

Marketeers Editor. (2012). Pasar Halal Dunia Capai USD 2,3 Triliun. Retrieved from: http:/ / marketeers.com/pasar-halal-dunia-capai-usd-23-triliun/

Mulyono, D. (2016). Pengaruh Media Sosial Terhadap Keputusan Memberikan Donasi pada Rumah Zakat [Tesis]. Bogor (ID): Institut Pertanian Bogor.

Qaradhawi, Y. (2013). Halal dan Haram. Bandung (ID): Penerbit Jabal.

Rajagopal, S. (2011). Halal Certification: Implication for Marketers in UAE. Journal of Islamic Marketing, Vol. 2(2).

Salehudin, I. Mukhlish, B.M. (2012). Pemasaran Halal: Konsep, Implikasi dan Temuan di Lapangan. Kumpulan Tulisan Ekonom Muda FEUI: 293-305. Jakarta (ID): Lembaga Penerbit Fakultas Ekonomi UI.

Santoso, D. (2016). Faktor-Faktor yang Mempengaruhi Minat Beli padaPrivate Label Foods [Tesis]. Bogor (ID): Institut Pertanian Bogor.

Senthilnathan, S. and Tharmi, U. (2012). The Relationship of Brand Equity to Purchase Intention. The IUP Journal of Marketing Management, Vol. 11(2).

Syahruddin. (2014). Potensi Kemajuan Umat Melalui Produk Halal. Retrieved from: http://majalahgontor.net/potensi-kemajuan-umat-melaluiproduk-halal/. 
Tieman, M. and Ghazali, MC. (2013). Principles in Halal Purchasing. Journal of Islamic Marketing, Vol. 4(3): 281-293.

Wang, EST. (2015). Effect of Food Service-Brand quity on ConsumerPerceived Food Value, Physical Risk, and Brand Preference. British Food Journal, Vol. 117(2).

Wang, Y.H. and Tsai, C.F. (2014). The Relationship Between Brand Image and Purchase Intention: Evidence from Award Winning Mutual Funds. The International Journal of Business and Finance Research, Vol. 8(2).

Wu Paul, C.S. Yeh, G.Y. Hsiao, C. (2011). The Effect of Store Image And Service Quality on Brand Image and Purchase Intention for Private Label Brands. Australian Marketing Journal, Vol. 19: 30-39. 